\title{
Pengembangan Perangkat dan Model Pembelajaran Open Ended Learning Melalui Media Audiovisual dan Media Grafis Pada Materi Media Promosi
}

\author{
Fina Nurul Baidlok ${ }^{1}$, Elis Irmayanti², Bayu Surindra ${ }^{3}$ \\ finayasmine28@gmail.com¹, elis@unpkediri.ac.id², bayusurindra@unpkediri.ac.id² \\ Program Studi Pendidikan Ekonomi, FEB, Universitas Nusantara PGRI Kediri123
}

\begin{abstract}
This research is motivated by the lack of student achievement levels of a subject due to learning carried out in conventional schools and less creative. This can be seen from the low psychomotor scores of students, which ultimately have an impact on learning outcomes below. In addition, school facilities are not evenly distributed, so that it has an impact on the enthusiasm of students to take part in learning. Therefore, the aim of this research is to find out the process of developing tools and learning models for Open-Ended Learning through audiovisual media and graphic media on promotional media materials for product marketing. This study uses a model research approach with research subjects a team of experts consisting of three people who are experts in why in their respective. The research was carried out in two stages, namely, two times the expert validation test. The results of this development research indicate very good criteria.
\end{abstract}

Keywords: learning media, open-ended learning model, audiovisual media, graphic media

\begin{abstract}
Abstrak
Penelitian ini dilatarbelakangi kurangnya tingkat pencapaian siswa terhadap suatu mata pelajaran dikarenakan pembelajaran yang dilaksanakan di sekolah konvensional dan kurang kreatif. Hal tersebut nampak dari rendahnya nilai psikomotor siswa yang akhirnya berdampak pada hasil belajar menjadi rendah. Selain itu, fasilitas sekolah belum merata sehingga memberikan dampak terhadap tingkat antusias siswa untuk mengikuti pembelajaran. Maka dari itu tujuan dalam penelitian ini yaitu untuk mengetahui proses pengembangan perangkat dan model pembelajaran Open Ended Learning melalui media audiovisual dan media grafis pada materi media promosi untuk pemasaran produk. Penelitian ini menggunakan model penelitian pengembangan dengan subyek penelitian tim ahli/ pakar yang terdiri dari tiga orang ahli pada bidangnya masing-masing. Penelitian dilaksanakan dengan dua tahapan yaitu dua kali uji validasi ahli. Hasil dari penelitian pengembangan ini menunjukan kriteria yang sangat baik dengan nilai tingkat validitas pertama perangkat silabus memperoleh prosentase $86,5 \%$, tahap validasi kedua dengan prosentase $93,5 \%$. Pada tingkat validitas RPP pada uji validitas pertama memperoleh prosentase $88,3 \%$, sedangkan pada tahap kedua memperoleh prosentase $97 \%$. Sedangkan pada uji validitas LKS pada tahap uji validasi pertama memperoleh hasil prosentase $83,3 \%$, sedangkan pada tahap kedua dengan perolehan prosentase $90 \%$.
\end{abstract}

Kata Kunci: perangkat pembelajaran, model pembelajaran open ended learning, media audiovisual, media grafis 


\section{PENDAHULUAN}

Kurikulum 2013 wajib dijadikan pedoman bagi setiap sekolah yang mewajibkan siswa berperan aktif dalam pembelajaran (Peraturan Menteri Pendidikan Dan Kebudayaan Tentang Implementasi Kurikulum, 2013). Hal tersebut seharusnya dipersiapkan oleh guru dengan matang sebelum pembelajaran berlangsung. Namun, banyaknya guru mengabaikan pentingnya menyiapkan perangkat pembelajaran sehingga pembelajaran di dalam kelas berjalan tidak interaktif. Selain itu, seringkali seorang guru hanya menggunakan model pembelajaran yang konvensional. Model pembelajaran digunakan oleh guru agar dapat berkomunikasi dengan aktif Ketika menyampaikan materi pembelajaran.

Model pembelajaran merupakan ialah landasan praktik pembelajaran dimana hasil penurunan dari psikologi pendidikan dan juga teori belajar yang dirancang berdasarkan analisis atas implementasi serta implikasinya terhadap tingkat operasional di dalam kelas (Suprijono, 2012). Selanjtunya dalam penelitian ini model pembelajaran yang digunakan yaitu model pembelajaran Open Ended Learning. Dimana model pembelajaran Open Ended Learning berfokus pada siswa yang diharapkan mampu mengembangkan ide kreatif, strategi dan pola piker yang sistematis dengan diberikannya masalah yang bersifat terbuka pada awal pembelajaran. Masalah yang disajikan harus bersifat kontekstual guna mengembangkan kemampuan berfikir siswa yang tentunya dikaitkan dengan materi selanjutnya (Suyatno, 2009).

Selanjutnya untuk menunjang keterlaksanaan model pembelajaran yang efisien juga diperlukan adanya media pembelajaran yang sesuai agar dapat mempermudah siswa dalam memahami pembelajaran. Dimana pembelajaran tanpa menggunakan media mengakibatkan siswa mengalami kejenuhan hingga pada akhirnya siswa kehilangan semangat belajar. Tentunya kegiatan pembelajaran tanpa berbantu media sangat tidak efektif karena dapat menghabiskan waktu belajar dan terkesan tidak menarik. Kita juga dapat memahami bahwa media adalah pembawa pesan yang mengandung makna pengajaran yang diyakini dapat lebih menumbuhkan tingkat motivasi belajar siswa (Arsyad, 2011). Kegiatan pembelajaran akan lebih inovatif dengan penggunaan media sebagai alat bantu dalam proses pembelajaran agar lebih mudah untuk memahami isi dari materi. Media bagaikan seluruh benda yang bisa dimanipulasi, dilihat, didengarkan, dibaca ataupun dibicarakan serta instrument yang digunakan buat aktivitas tersebut (Irmayanti \& Surindra, 2019). Media yang digunakan dalam penelitian ini adalah media audiovisual dan media grafis karena dengan media tersebut dianggap paling efisien untuk pembelajaran pada materi ini. Media audiovisual berciri khas dengan penggunaan mesin mekanis elektronik untuk menyampaikan pesan (Suryani \& Dkk, 2018). Selanjutnya media grafis adalah media visual yang menyalurkan pesan melalui lambang atau simbol komunikasi visual (Asnawir \& Basyiruddin, 2002).

Maka dari itu, perangkat pembelajaran disertai dengan model pembelajaran yang sesuai dengan lingkungan belajar yang mendukung dan ditambahkan media pembelajaran yang baik adalah suatu hal yang penting untuk diperhatikan. Hal ini disebabkan karena perangkat pembelajaran digunakan guru sebagai pedoman atau perlengkapan dalam kegiatan pembelajaran (Prasetyo, 2011). Perangkat pem;belajaran ialah merupakan seluruh 
komponen perlengkapan serta bahan yang digunakan guru buat melaksanakan proses Pendidikan (Chodijah et al., 2012). Perangkat pembelajaran pada materi media promosi yang dikembangkan adalah Silabus, RPP dan LKS. Sementara berdasarkan hasil pendahuluan penelitian yang dilakukan dengan observasi pada sekolah SMK PGRI 2 Kediri menemukan beberapa permasalahan salah satunya adalah kurangnya kesiapan guru dalam melakukan kegiatan pembelajaran yang diiringi dengan tidak adanya perangkat pembelajaran. Selain itu, siswa cenderung malas untuk mengikuti kegiatan pembelajaran yang kurang kreatif alhasil berdampak pada hasil pencapaian siswa di dalam kelas.

Berdasarkan beberapa permasalahan di atas tujuan dari penelitian ini adalah mendeskripsikan pengembangan perangkat dan model pembelajaran Open Ended Learning melalui media audiovisual dan media grafis pada materi media promosi.

Tabel 1. Ringkasan Desain Perangkat

\begin{tabular}{|c|c|c|}
\hline No. & Komponen & Uraian \\
\hline 1. & Silabus & $\begin{array}{l}\text { Capaian pembelajaran, kemampuan akhir yang direncanakan, indikator } \\
\text { pencapaian kompetensi, materi pokok, tahapan kegiatan, penilaian, } \\
\text { referensi yang digunakan }\end{array}$ \\
\hline 2. & RPP & $\begin{array}{l}\text { Capaian pembelajaran, kemampuan akhir yang direncanakan, indikator } \\
\text { pencapaian kompetensi, materi pokok, langkah kegiatan, bentuk } \\
\text { pembelajaran (metode belajar), penilaian dan referensi yang digunakan }\end{array}$ \\
\hline 3. & Modul & Modul dibuat sendiri oleh peneliti \\
\hline 4. & $\begin{array}{l}\text { Lembar Kegiatan } \\
\text { Siswa }\end{array}$ & $\begin{array}{l}\text { Petunjuk kegiatan, instrumen penugasan individu maupun kelompok, } \\
\text { penilaian }\end{array}$ \\
\hline 5. & Media pembelajaran & Slide presentasi, buku, media audiovisual dan media grafis \\
\hline 6. & Model pembelajaran & Model Open Ended Learning sesuai dengan materi yang disampaikan \\
\hline 7. & Penilaian & Aspek kognitif, afektif, dan hasil diskusi \\
\hline
\end{tabular}

\section{METODE PENELITIAN}

Penelitian ini ialah jenis penelitian pengembangan atau research and development. Penelitian dan pengembangan merupakan metode penelitian yang dipergunakan dalam menghasilkan produk tertentu serta menguji efektifitas produk tersebut (Sugiyono, 2017). Penelitian pengembangan ini digunakan untuk menguji keefektifan produk tertentu yang telah berhasil dikembangkan. Selain itu, penelitian ini menghasilkan sebuah produk penyempurnaan dari produk yang telah ada. Penelitian pengembangan ini menggunakan model pengembangan plomp 1997 (Rochmad, 2012). Subjek penelitian ini adalah tim uji ahli atau validator pakar. Penelitian ini bertempat pada Universitas Nusantara PGRI Kediri yang dilaksanakan mulai bulan Agustus 2019-Juli 2020. Prosedur penelitian ini terdiri dari beberapa tahap seperti fase investigasi awal (prelimenary investigation), fase desain (design), fase realisasi atau konstruksi (realization/contruction), fase tes, evaluasi dan revisi (test, evaluation, and revision), fase implementasi (implementation). 


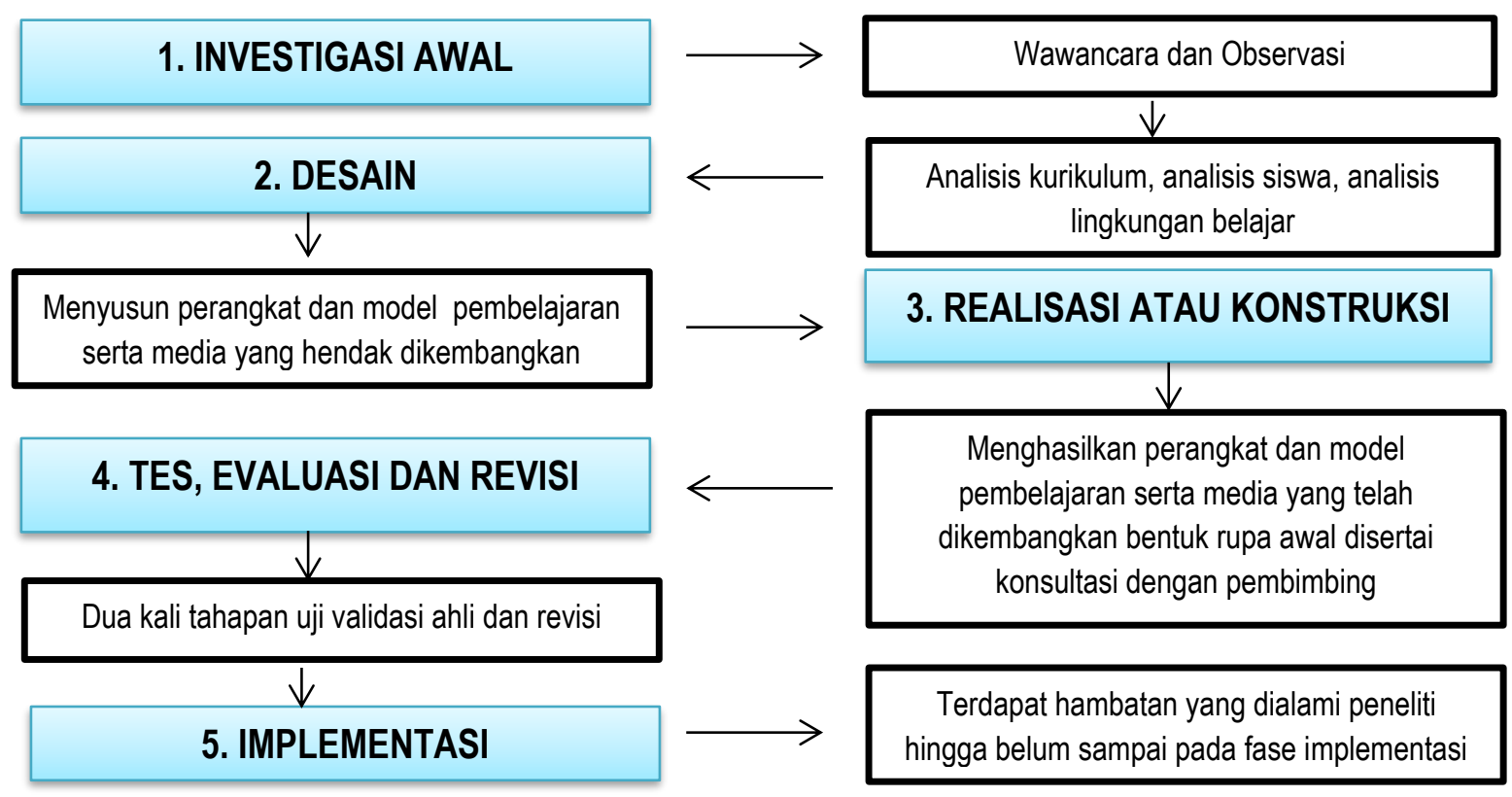

Gambar 1. Alur Penelitian Pengembangan Model Plomp (Rochmad, 2012) Keterangan:

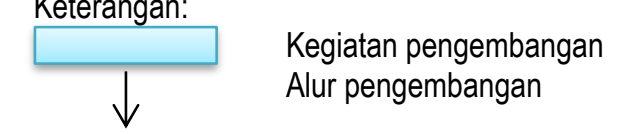

Alur penelitian pengembangan menggunakan model Plomp diharapkan dapat mempermudah pembaca dalam memahami desain penelitian model pengembangan yang digunakan. Desain uji coba produk dalam penelitian ini menggunakan desain umum dipakai dalam penelitian lainnya, yaitu desain deskriptif. Uji coba perangkat dan model pembelajaran Open-Ended Learning ini memiliki desain dengan tahapan khusus yaitu uji coba kelompok kecil dengan melakukan uji validasi sebanyak dua kali. Uji coba kelompok kecil tersebut dapat dikategorikan dengan pengujian terbatas. Subjek uji coba pada penelitian pengembangan ini terdiri dari ahli dari beberapa bidang, seperti ahli bahasa, ahli isi produk, dan ahli media. Indikator penilaian pada produk yang dikembangkan dalam penelitain ini dengan melakukan uji validitas yang terdiri dari uji validitas isi dan uji validitas konstruk.

Instrumen pengumpulan data uji coba dalam penelitian ini adalah lembar validasi perangkat dan model pembelajaran yang terdiri dari lembar validasi silabus, RPP, LKS. Lembar validasi tersebut diberikan kepada para ahli (validator) bersama perangkat pembelajaran yang akan divalidasi. Intrumen yang digunakan dalam penelitian ini digunakan untuk memperoleh data yang diharapkan oleh peneliti yang selanjutnya akan diolah oleh peneliti. Data yang diperoleh peneliti dari pengembangan perangkat dan model pembelajaran yang telah dinyatakan valid oleh para ahli dianalisis menggunakan metode deskriptif kuantitatif. Instrumen validasi yang digunakan berisi jawaban dengan perbandingan skor menggunakan skala likert yaitu 4,3,2,1. Adapun skala penilaian memiliki makna 1 (tidak baik), 2 (kurang baik), 3 (baik), 4 (sangat baik). Instrumen dapat dikatakan valid apabila instrumen tersebut dapat dengan tepat mengukur apa yang hendak diukur (Widoyoko, 2012). Validitas dengan kata lian "ketepatan" dengan alat ukur. Intrumen yang digunakan dalam penelitian ini 
digunakan untuk memperoleh data yang diharapkan oleh peneliti yang selanjutnya akan diolah oleh peneliti.

Dalam penelitian pengembangan hasil dari pengembangan dapat berupa model atau rancangan saja. Sedangkan, untuk memperoleh hasil dari pengembangan yang berkualitas hendaknya dilakukan penilaian atau pengujian. Indikator penilaian pada perangkat dan model pembelajaran yang dikembangkan dengan melakukan uji validitas yang terdiri dari uji validitas isi dan uji validitas konstruk.

\section{Validitas isi}

Validitas isi menunjukan desain produk yang dikembangkan berdasarkan kurikulum atau model pembelajaran yang dikembangkan berdasarkan pada teoritik yang kuat. Teori yang mendasari perkembangan model pembelajaran dijelaskan secara mendalam. Sebagai contoh teori pengembangan pembelajaran yang dibutuhkan seperti teori pembelajaran psikologi kognitif ataupun teori pengembangan model pembelajaran lainnya.

\section{Validitas konstruk}

Validitas konstruk menunjukan konsistensi antar komponen-komponen model yang terdapat pada perangkat yang dikembangkan. Hal tersebut ditunjukan dalam hubungan komponen model yang dikembangkan di dalamnya seperti, sintaks, sistem sosial, sistem pendukung, dan dampak langsung maupun dampak tidak langsung. Pada hakikatnya validitas konstruk ini secara rinci menunjukan hubungan antar komponen dalam produk yang dikembangkan tidak bertentangan.

\section{HASIL DAN PEMBAHASAN}

Berdasarkan hasil penelitian dapat diketahui bahwa pengembangan perangkat dan model pembelajaran Open Ended Learning melalui media audiovisual dan media grafis pada materi media promosi mencapai tingkat kevalidan dengan kategori sangat baik. Adapun hasil dari penelitian ini disesuaikan dengan model pengembangan yang digunakan. Pada fase investigasi awal peneliti menemukan kesenjangan antara apa yang terjadi dengan situasi yang dikehendaki dalam oembelajaran di dalam kelas. Selanjutnya, peneliti melakukan beberapa analisis guna menentukan solusi dari kelanjutan proyek yang hendak dikerjakan, seperti analisis kurikulum, analisis siswa dan analisis lingkungan belajar. Data yang diperoleh pada fase investigasi awal dikumpulkan guna menyusun perangkat dan model pembelajaran melalui media yang hendak dikembangkan.

Pada fase desain peneliti merancang perangkat dan model pembelajaran Open Ended Learning melalui media audiovisual dan media grafis yang disesuaikan dengan kurikulum dan lingkungan belajar siswa. Tentunya media audiovisual dan media grafis yang dirancang ditentukan disesuaikan dengan materi media promosi. Tahap lanjutan dari fase desain adalah bentuk rupa pertama desain perangkat dan model pembelajaran melalui media audiovisual dan media grafis dengan dikonsultasikan dengan dosen pembimbing sebelum dilaksanakan validasi. Tahap terakhir penelitian ini pada fase tes, evaluasi dan revisi diadakannya dua kali tahapan uji validasi ahli dengan melakukan revisi sesuai saran serta petunjuk dari validator. Penilaian yang dilakukan oleh validator meliputi aspek, yaitu format 
yang disajikan, bahasa yang digunakan, waktu yang disesuaikan dan isi perangkat dan model pembelajaran melalui media pembelajaran.

Uji validasi ahli dilaksanakan dua kali dengan hasil yang berbeda pada setiap aspek. Berdasarkan lembar validasi oleh tiga ahli pada perangkat dan model pembelajaran melalui media pembelajaran diperoleh nilai sebagai berikut:

\section{Validasi Silabus}

Berdasarkan ketiga validator dengan melaksanakan pengujian validasi sebanyak dua kali memberikan penilaian pada silabus diperoleh hasil sebagai berikut:

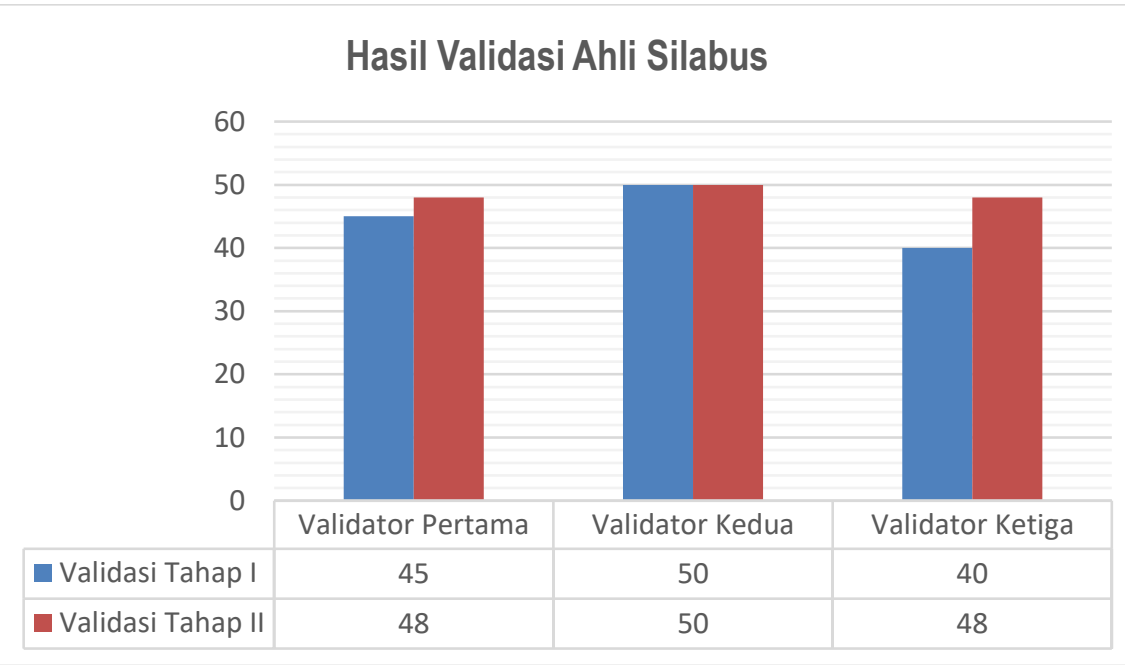

Gambar 2. Hasil Validasi Ahli Silabus (Hasil penelitian yang diolah, 2020)

Teknik analisis data penelitian pengembangan ini dengan menghitung prosentase, hasil analisa data hasil uji ahli silabus pada tahap pertama sebagai berikut:

$P=\frac{135}{156} \times 100 \%=86,5 \%$

Sedangkan hasil uji ahli silabus pada tahap kedua sebagai berikut:

$P=\frac{146}{156} \times 100 \%=93,5 \%$

Berdasarkan nilai yang diberikan oleh validator ahli diatas, dapat diketahui bahwa nilai validasi pada tahap pertama memperoleh total skor 135 dengan hasil persentase $86,5 \%$ dengan kriteria nilai baik. Pada hasil uji validasi kedua jika dimasukan dalam prosentase memperoleh nilai 93,5\%. Hal ini menandakan silabus yang disusun dan dikembangkan dalm penelitian ini telah layak dan dapat di implementasikan.

\section{Validasi RPP}

Berdasarkan tiga ahli, uji validasi ahli pada perangkat RPP memperoleh nilai sebagai berikut: 
Efektor, Volume 7 Issue 2, 2020, Pages 117-126

Fina Nurul Baidlok, Elis Irmayanti, Bayu Surindra



Gambar 3. Hasil Validasi Ahli RPP (Hasil penelitian yang diolah, 2020)

Teknik analisis data penelitian pengembangan ini dengan menghitung prosentase, hasil analisa data hasil uji ahli RPP pada tahap pertama sebagai berikut:

$$
P=\frac{159}{180} \times 100 \%=88,3 \%
$$

Sedangkan hasil uji ahli pada RPP tahap kedua sebagai berikut:

$$
P=\frac{176}{180} \times 100 \%=97 \%
$$

Berdasarkan nilai yang telah diberikan oleh validator terhadap perangkat dan model pembelajaran melalui media pembelajaran pada validasi pertama, komponen RPP telah memenuhi kriteria layak. Pada tahap uji validasi pertama dari ketiga validator memberikan skor dengan total skor 159. Pada uji validasi pertama memperoleh range presentase $88,3 \%$. Sedangkan pada tahap uji validasi kedua, total skor yang diperoleh adalah 176 dengan hasil prosentase mencapai $97 \%$. Tentunya hal tersebut menunjukan bahwa perangkat RPP sangat layak untuk diterapkan.

\section{Validasi LKS} skor berikut:

Berdasarkan lembar validasi komponen LKS yang dinilai oleh validator diperoleh

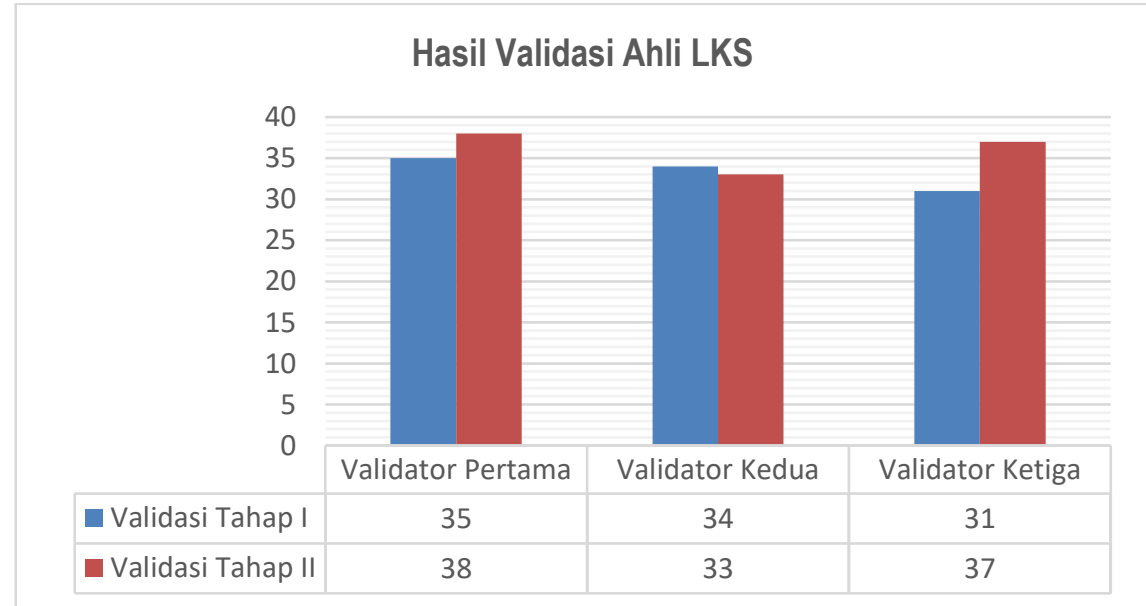

Gambar 4. Hasil Validasi Ahli LKS (Hasil penelitian yang diolah, 2020) 
Teknik analisis data penelitian pengembangan ini dengan menghitung prosentase, hasil analisa data hasil uji ahli LKS pada tahap pertama sebagai berikut:

$$
P=\frac{100}{120} \times 100 \%=83,3 \%
$$

Sedangkan hasil uji ahli pada perangkat LKS tahap kedua sebagai berikut:

$$
P=\frac{108}{120} \times 100 \%=90 \%
$$

Berdasarkan hasil uji validasi oleh ahli yang diselenggarakan dua kali pada komponen LKS, dapat dilihat total skor pertama yaitu 100 dengan hasil prosenstase $83,3 \%$. Meski diperoleh nilai dengan taraf keberhasilan baik tetap dilangsungkan uji validasi kedua. Pada tahap uji validasi kedua memperoleh total skor 108 dengan tingkat prosentase $90 \%$. Dilihat dari perkembangan hasil uji validasi maka komponen LKS mampu dinyatakan sangat baik dan layak jika diterapkan.

Berikut taraf keberhasilan tindakan pengembangan atau tingkat kelayakan perangkat pembelajaran melalui uji coba kelompok kecil dilihat dalam aspek kualitatif, yaitu:

Tabel 2. Penentu Taraf Keberhasilan Tindakan (Arikunto, 2008)

\begin{tabular}{cc}
\hline Prosentase ketuntasan & Taraf Keberhasilan \\
\hline $90-100$ & Sangat baik \\
\hline $80-89$ & Baik \\
\hline $70-79$ & Cukup \\
\hline $60-69$ & Kurang \\
\hline$\leq 59$ & Sangat kurang
\end{tabular}

Berdasarkan hasil uji validasi diperoleh data yang menunjukan bahwa tingkat kevalidan yang diperoleh pada perangkat dan model pembelajaran melalui media pembelajaran sudah masuk kategori sangat baik dengan melalui dua kali uji validasi ahli. Perangkat layak digunakan dengan melakukan beberapa tahap revisi. Pada tingkat kepraktisan dan keefektifan pengembangan perangkat dan model pembelajaran melalui media pembelajaran ini belum dapat diketahui hasilnya dikarenakan keterbatasan waktu peneliti untuk implementasi. Adanya hambatan yang benar-benar membuat peneliti tidak dapat meneruskan penelitian ini hingga tahap akhir yakni pandemic Covid-19

Perangkat dan model pembelajaran melalui media pembelajaran yang telah disusun dan dikembangkan sesuai dengan standar kompetensi penyusunan kurikulum 2013. Setelah dilakukannya pengujian validasi kepada ahli maka diperoleh susunan produk yang telah berhasil dikembangkan. Perangkat dan model pembelajaran dengan media pembelajaran yang siap digunakan dan dinyatakan layak oleh ahli disebut desain akhir pengembangan. Pada tahap desain akhir pengembangan ini menemukan beberapa poin penting pembeda pada perangkat dan model pembelajaran melalui media pembelajaran yang disusun pada umumnya. Berikut tabel penjelasannya:

Tabel 3. Desain Akhir Model Pengembangan

\begin{tabular}{lll}
\hline No. & $\begin{array}{c}\text { Perangkat } \\
\text { Pembelajaran }\end{array}$ & \multicolumn{1}{c}{ Keterangan } \\
\hline 1. & Silabus & $\begin{array}{l}\text { 1. Kegiatan pembelajaran menggunakan kata kerja operasional yang sesuai } \\
\text { dengan materi }\end{array}$ \\
\hline
\end{tabular}




\begin{tabular}{|c|c|c|}
\hline & & $\begin{array}{l}\text { 2. Setiap materi mengharuskan penilaian dengan aspek psikomotor } \\
\text { 3. Kegiatan pembelajaran disesuaikan dengan pembelajaran online }\end{array}$ \\
\hline 2. & RPP & $\begin{array}{l}\text { 1. Disusun dengan penyesuaian terhadap aspek kognitif siswa } \\
\text { 2. Disusun dengan metode pembelajaran online } \\
\text { 3. Model pembelajaran dipilih untuk meningkatkan kemampuan berfikir kritis } \\
\text { siswa } \\
\text { 4. Media pembelajaran yang digunakan berbasis online } \\
\text { 5. Remedial terstruktur }\end{array}$ \\
\hline 3. & LKS & $\begin{array}{l}\text { 1. Prosedur penilaian dilaksanakan dengan tugas yang bervariasi } \\
\text { 2. Pembuatan tugas didasari oleh prinsip High Order Thinking Skill } \\
\text { 3. Penerapan sistem pembelajaran online }\end{array}$ \\
\hline
\end{tabular}

\section{SIMPULAN}

(Hasil penelitian yang diolah, 2020)

Berdasarkan analisis data dan pembahasan hasil penelitian dapat diambil kesimpulan dari penelitian ini proses pengembangan perangkat dan model pembelajaran Open Ended Learning (OEL) melalui media audiovisual dan media grafis pada materi media promosi dalam penelitian ini menggunakan model Plomp yang dirangkum menjadi empat tahapan yakni tahap investigasi awal, tahap desain, tahap realisasi atau konstruk, tahap tes, evaluasi dan hasil melalui dua tahapan uji validasi ahli dan revisi menunjukan tingkat kriteria yang sangat baik sehingga mampu dikatakan memenuhi kriteria valid. Tingkat validitas yang diperoleh pada penelitian pengembangan ini pada tahap pertama penilaian Silabus memperoleh total skor 135 dengan tingkat prosentase $86,5 \%$. Sedangkan pada tahap kedua uji validitas silabus memperoleh total skor 146 dengan tingkat prosentase 93,5\%. Perangkat pembelajaran komponen RPP pada uji validasi ahli memperoleh total skor 159 dengan prosentase $88,3 \%$. Pada tahap kedua uji validitas RPP yang dilakukan oleh tiga ahli memperoleh total skor 176 dengan prosentase 97\%. Perolehan skor dengan prosentase tersebut mendapatkan tingkat kevalidan sangat baik. Perangkat pembelajaran komponen LKS berhasil dikembangkan dan di uji validasi ahli dengan memperoleh total skor pertama 100 dengan jumlah prosentase $83,3 \%$. Pada tahap uji validasi kedua diperoleh total skor 108 dengan tingkat prosentase $90 \%$.

\section{DAFTAR RUJUKAN}

Arikunto, S. (2008). Prosedur Penelitian Suatu Pendekatan Praktik. Rhineka Cipta.

Arsyad, A. (2011). Media Pembelajaran berbasis SETS. PT. Raja Grafindo Persada.

Asnawir, \& Basyiruddin, U. (2002). Media Pembelajaran. Ciputat Pers.

Chodijah, S., Fauzi, A., \& Wulan, R. (2012). Pengembangan Perangkat Pembelajaran Fisika Menggunakan Model Guided Inquiryyang Dilengkapi Penilaian Portofolio Pada Materi Gerak Melingkar. Jurnal Penelitian Pembelajaran Fisika.

Irmayanti, E., \& Surindra, B. (2019). Peningkatan Penguasaan Konsep "Kebijakan Fiskal dan Moneter" Melalui Model Pembelajaran Mandiri Aktif Bermedia Audio Visual pada Siswa Kelas XI-1 SMA Negeri 4 Kediri. Proceedings of the ICECRS, 2(1), 273-280. https://doi.org/10.21070/picecrs.v2i1.2384

Peraturan Menteri Pendidikan dan Kebudayaan Tentang Implementasi Kurikulum, Pub. L. No. 65 (2013).

Prasetyo, Z. K. (2011). Pengembangan Perangkat Pembelajaran Sains Terpadu Untuk 
Meningkatkan Kognitif, Keterampilan Proses, Kreativitas Serta Menerapkan Konsep IImiah Peserta Didik Smp. Universitas Negeri Yogyakarta.

Rochmad. (2012). Desain Model Pengembangan Perangkat Pembelajaran Matematika. Jurnal Matematika Kreatif-Inovatif (KREANO), 3(1), 59-72.

https://journal.unnes.ac.id/nju/index.php/kreano/article/view/2613/2672

Sugiyono. (2017). Metode Penelitian Pendidikan (Pendekatan Kuantitatif, Kualitatif, dan R\&D). Alfabeta.

Suprijono, A. (2012). Cooperative Learning. Pustaka Pelajar.

Suryani, N., \& Dkk. (2018). Media pembelajaran Inovatif dan Pengembangannya. PT. Remaja Rosdakarya.

Suyatno. (2009). Menjelajah Pembelajaran Inovatif. Masmedia Buana Pustaka.

Widoyoko, E. P. (2012). Teknik Penyusunan Instrumen Penelitian. Pustaka Pelajar. 